\title{
Education in Diversity - Diversity in Education: Students with Visual Disabilities in the Sultanate of Oman ${ }^{i}$
}

\author{
Annemarie Profanter, Rebecka Näslund and Shariffa Al-Said
}

To cite this article: Profanter, A. \& Näslund, R. and Al-Said, S. (2018). Education in Diversity Diversity in Education Students with Visual Disabilities in the Sultanate of Oman. Al Raida, 42(2), 1-21. DOI: 10.32380/alrj.v42i2.1739

To link to this article: http://dx.doi.org/10.32380/alrj.v42i2.1739

(c) 2018 The Author(s)

Corresponding author: Annemarie Profanter

Author contact: Annemarie.profanter@unibz.it

Article type: Research article

Article accepted: 24th October 2018

Published online: $30^{\text {th }}$ November 2018

Publisher: Institute for Women's Studies in the Arab World

Publication support provided by: Escienta

Journal ISSN: 0259-9953

Copyright: This is an Open Access article, free of all copyright, and may be freely reproduced, distributed, transmitted, modified, built upon, or otherwise used by anyone for any lawful purpose. The work is made available under the Creative Commons Attribution (CC-BY) 4.0 license. 


\section{Education in Diversity - Diversity in Education: Students with Visual Disabilities in the Sultanate of Oman} Annemarie Profanter ${ }^{1}$, Rebecka Näslund ${ }^{2}$ and Shariffa Al-Said ${ }^{3}$

1 Facoltà di Scienze della Formazione, Libera Università di Bolzano, Italy

2 Department of Business Administration, Technology and Social Sciences, Luleå University of Technology, Sweden

3 Specialized Centre for the Professional Training of Teachers, Ministry of Education, Sultanate of Oman

\section{Abstract}

In this article, disability and its interplay with gender in the Sultanate of Oman are explored. Previous research on this issue in Oman has been conducted adopting a medical model. Consequently, the interrelations between the individual and wider society in relation to disability have only been marginally researched. This research, however, explores the interrelation of disability and gender and the co-construction of their meanings for students with visual disabilities. In comparison with other studies - particularly in the Arabian Gulf, where disability is often explored from the standpoint of caregivers, politicians, etc. - this research specifically strives to include disabled students' views and social experiences. Moreover, the interplay between educational, religious, and cultural practices is analyzed. Quantitative and qualitative data were gathered at the only state-run school for students with visual disabilities in the capital area. The sample is balanced by gender and comprises 30 students aged 14-23, as well as one key religious figure and one representative of a non-governmental organization. The study shows that despite investments and awareness-raising campaigns, various forms of social practice exist that construct and reconstruct the meanings of disability and gender. Additionally, it is revealed that there is a 
political need to initiate a relational model of gender and disability to further improve the situation for students with disability in Oman.

Keywords: Disability, gender, education, information and communications technology, Sultanate of Oman

Introduction

Research regarding disability in Omani society is scarce. As Al-Mawali (2004) highlights, studies focusing on the social issues that pertain to the everyday lives of people with disabilities in Oman are limited. According to Al-Mawali (2004, p. 10), "most research, into disability in Oman, has been based on the medical approach and used quantitative methods only." Research from this biomedical angle has focused mostly on professional practices, agencies, and services provided for people with disabilities, and only to a limited extent on the everyday lives of people with disabilities. Examples of this type of research are: a) a study by Khandekar, Mohammed, Negrel, and Al Riyami (2002) that focuses on the occurrence and causes of blindness; b) research focusing on the National Register for the Blind (Khandekar \& Al Harby, 2006); c) reviews of programs that focus on blindness and partial sight (Khandekar, Mohammed, \& Al Raisi, 2007); and d) the prevalence of disability in Oman, the challenges that exist, and recommendations for improving services (Al-Balushi, Al-Badi, \& Ali, 2011). Another strand of research focuses on: a) special education in Oman (Ohlin, 1995); b) children with visual disabilities and their education (Hadidi, 1998); c) disability, discourse, and agency (Al Zidjaly, 2007, 2009); d) services for children and young people with disabilities in Oman (Profanter, 2009); and e) inclusion into higher education for students with disabilities (Alqaryouti, 2010). There is some research that strives to include the voices of people with disabilities and their relationship to wider Omani society (Al-Mawali, 2004). This type of research takes the interrelations between the individual and wider society as its starting point. However, research remains limited on the intersections between the everyday lives of children and young people with disabilities, the educational arena, the family, and wider Omani society (Al-Mawali, 2004). As the literature review reveals, there is a need to further investigate 
the intersection of these issues with gender and disability.

This article is concerned with the everyday lives of students with visual disabilities in Oman. Unlike previous studies, our study focuses on: a) families and religious practices; b) educational aspirations of young people with visual disabilities; c) young people's access to and use of technology, such as computers, mobile devices, and assistive technologies; d) their future aspirations; and e) gender differences in terms of variables a, b, c, and d. The participants included in the study are blind and partially sighted students. We are interested in exploring how these students interact with wider Omani society. Thus, we look at their family situation, the educational realm, government policies, and religious and cultural customs. In Oman, specific practices exist that construct and reconstruct the meanings of disability in young people's lives. Moreover, we trace the gendering processes in a similar way. Gender has a relational meaning and is practiced and constructed in everyday life, e.g. in educational and religious settings and family practices. The aim of this study is to outline how students with visual disabilities themselves evaluate their disability.

This exploratory study was conducted during 2009-2011ii and combines both theoretical and empirical approaches. The research included personal field visits by the researchers to nongovernmental organizations (NGOs) working on disability, and to all Oman's special schools for pupils with disabilities, including the only school for students with visual disabilities. This timeconsuming approach was adopted to gain a detailed overview of the organizations and their model(s) of disability. Additionally, readings of relevant literature helped us to gain deeper insight into the topic of disability. The study draws on empirical research through interviews with students with visual disabilities. Background information was also gathered from the vice-president of a disability $\mathrm{NGO}^{\mathrm{iii}}$ and an imam in the region of Muscat, Oman's capital. An interdisciplinary approach was adopted to interpret the findings.

The following research questions are addressed in this paper, with a focus on gender differences among students with visual disabilities: how do the students evaluate their treatment by family members in relation to their visual disabilities? Are there any restrictions on their practicing religion? What are the students' personal experiences in relation to education, e.g. 
access to educational institutions, educational material, etc.? Do they have access to technology in their everyday lives? How do they evaluate their own future aspirations?

\section{Disability and Gender}

Previous ways of exploring disability, such as the individual model, focused on the individual and her/his body (Shakespeare, 2006). This individual model was criticized and reconceptualized, and thus a social model was developed. Its proponents argued that disability is constructed and reconstructed by wider society (cf. Oliver, 1996, p. 32). The relational model evolved later, and it takes both the individual body and wider society into consideration simultaneously (Näslund \& Gardelli, 2013, p. 30). According to this model, it is the relationship between the individual body (impairment) and the wider society (environmental aspects, encounters between practitioners, etc.) that creates disability (Shakespeare, 2006, p. 57). The current study draws upon interdisciplinary work, and it is based on disability studies that take a relational approach to disability and gender: the students' everyday lives and bodies - in other words, the fact that they live with blindness or partial sight - are seen in relation to wider Omani society. Interpreted in this way, disability is co-constructed and reconstructed in the relationship between students' everyday lives and bodies and wider society.

As Abu-Habib (1997a, p. 2) states, there is a lack of research in the Middle East that considers women, gender, and the interrelations of the two with disability. For her, the changes one wishes to achieve in the area of disability cannot be successful if gender is not considered a key variable (Abu-Habib, 1997a, p. 8). Thus, the interrelation between gender and disability is key for this study, which builds on gender studies inspired by feminist scholars such as Braidotti (2002) and Butler (1999, 2004). For our working definition of gender, we draw on Braidotti (2002):

The concept of gender refers to the many and complex ways in which social differences between the sexes acquire a meaning and become structural factors in the organization of social life. Gender is a cultural and historical product, as opposed to an essentialist definition of the physical differences between the sexes (pp. 286-287). 
We use the concept of gender in the relational sense that gender is "done" in everyday life; similarly to Braidotti (2002, p. 287), we consider that the concept refers to both women and men. Braidotti (2002, p. 287) states that it is important to include the diversity found among women and men, such as differences of ethnicity, age, religion, class, and sexual orientation. ${ }^{\text {iv }}$ Traustadóttir and Kristiansen (2004, p. 37) highlight that Braidotti's work omits disability as part of the diversity of women's lives. Disability is an important issue that shapes the everyday lives of both women and men and interrelates with other practices. Also, it is through relations between the individual and wider society that gender is co-constructed and reconstructed. As Atshan (1997, p. 53) argues: "the issues of disability and gender cannot be divorced from their socioeconomic and historical context. It is widely recognized nowadays that disability must be studied as part of a cultural matrix, affected by other important factors such as gender, and economic and political status." Thus, by treating gender and disability as intertwined, we are able to explore how they are rooted in cultural and historical processes in Omani society, and how this in turn relates to how students with visual disabilities evaluate their disability and their position in society.

\section{Context and Contextualization}

Not only social, religious, cultural, and historical but also geographical issues come into play when one investigates this topic. The regions of Oman are highly varied. Its primary population is divided by hundreds of miles of harsh territory, and this affects the structures of its social support systems. Other Gulf States such as the United Arab Emirates, Bahrain, and Kuwait are comprised primarily of large urban centers with large population blocks, whereas the Sultanate of Oman covers much larger geographical regions and features, encompassing extended rural areas.

Omani society is based on strong tribal ties (Al-Barwani \& Albeely, 2007). This tribal system continues to address people's well-being (Al-Barwani \& Albeely, 2007, p. 122), and has long functioned as a social network for the less advantaged. Islam is the state religion in Oman. The nature of Islam in the Arabian Gulf assures engagement in support for citizens with disabilities and 
provides a religious-cultural framework from within which to apply both international and national criteria for quality of life. Islam's prescriptive nature requires that all societal members have access to its teachings.

Social, religious, and cultural biases play a crucial role, although under both sharia and international law people with disabilities enjoy the same rights as all other Omani citizens (International Trade Union Confederation, 2008). The Ministry of Education (2008a, p. 63) emphasizes that it is important to overcome social and cultural hindrances in order to create change. In Oman there is a burgeoning lobby to champion the rights of persons with disabilities. This lobby is fully supported by the Sultan, but it is centered primarily on the Ash Sharqiyah region and the seven village centers that comprise Muscat; thus, this lobby too is limited by the available infrastructure. Although there is an increasing awareness of the need for professional centers and trained experts, all too often their foothold is precarious, made tenuous by the tensions between the actual needs of people with disabilities and definitions of cultural appropriateness in terms of professional training and practice (cf. Al-Krenawi, Graham, Dean, \& Eltaiba, 2004; Ashencaen Crabtree, 2008).

In a relatively short time, His Majesty Sultan Qaboos bin Said Al Said has created " modern infrastructure, spotless streets, and a highly professional military that devotes much of its budget to civic action" (Miller, 1997, p. 13). For example, the education system has developed rapidly, from three schools with 30 teachers and 900 students in 1970 (Ministry of Education, 2008a, p. 18) to 1,040 schools with 44,000 teachers and 531,000 students in 2009 (Ministry of National Economy, n.d.a). Furthermore, education was only available for boys in 1970, while today it is available for both girls and boys (Al-Barwani \& Albeely, 2007). In 1970 students with disabilities had no access at all to education (Ministry of Education, 2008a, p. 18), whereas today special schools and care centers are being set up, mainly in the urban centers (Profanter, 2009).

\section{The Disability Network}

Policy changes for people with disabilities have occurred in Oman, such as: a) the Sultan's Basic Law, a form of constitution (Miller, 1997, p. 13); b) the inclusion of students with disabilities; 
c) the development and widespread dissemination of an Arabic sign language; d) a relatively rapid growth of specialized centers; and e) Royal Decree 63/2008, which emphasizes the right to education and training for persons with disabilities (Ministry of Education, 2008a, p. 59). Royal Decree 63/2008 defines a disabled person as:

[A] person who suffers from a congenital shortage of some of his sensory, physical or mental abilities, or as a result of a genetic factor, disease or accident which limits his ability to perform his natural role in life compared to his age group and is in need of welfare and rehabilitation to play his role in life (cited in Ministry of National Economy, n.d.b, p. 8).

Services for people with disabilities exist to various extents in Oman. The Ministry of Education and the Ministry of Social Development supervise these services. They are mostly located in the urban centers, and they are operated by the government, NGOs, and private initiatives. The Ministry of Health supervises healthcare services and focuses on the medical treatment and prevention of disability in Oman (Hadidi, 1998, p. 427). Regional businesses and community groups are investing in improving services and care for people with disabilities. The government is working with organizations such as the United Nations to develop issues around health and women's situation (Hadidi, 1998, p. 427).

Services for people with disabilities are specialized according to different types of disability and different age groups (cf. Profanter, 2009). The only association that deals with people with visual disabilities is the Al-Noor Association for the Blind, founded in 1997. Its official goals encompass integrating people with partial sight or blindness, showcasing their activities or skills through participation in religious celebrations, spreading awareness about the societal role and importance of people with visual disabilities, participating in volunteer work, and cooperating with the Ministry of Information to publicly advertise the activities of people with visual disabilities (Profanter, 2009).

In addition, some private schools, such as the Indian School Muscat and Muscat International School, offer some services for students with disabilities. Government ministries also provide services including schooling: special schools such as Al-Amal, a school for students with 
hearing disabilities founded in 1979; Al-Tarbiyah Al-Fikriyah, a school for students with intellectual disabilities, which has operated since 1984; and Omar Bin Al-Khattab Institute for the Blind, set up with support from the private sector in 1999 (Ministry of Education, 2008a). These state-run special schools are available - at least on paper - to all Omani students throughout Oman. Admission is granted by the school and the Ministry of Education, on production of medical proof of the student's disability.

Moreover, inclusive approaches are implemented in Oman to enable students with disabilities to access education in ordinary schools (Ministry of Education, 2008a; Ministry of Education, n.d.). The Ministry of Education supports this type of program on the grounds that there are no other special educational services available outside Muscat Governorate. Moreover, it enables students to stay in their community, and to aspire to more acceptance in society at large. It is important to highlight that according to the Ministry of Education, this inclusive approach is not solely meant for students with disabilities: "the broader definition of inclusive education implies catering not only for those with special education needs but for the diverse need of all learners" (Ministry of Education, 2008a, p. 55). However, the ministry is aware that "some students with severe physical or development disabilities [...] continue to be excluded from the education system" (p. 60).

Infrastructural investments are being made, such the implementation of information and communications technology (ICT) in education (Ministry of Education, 2008b, p. 7). There are initiatives to provide more ICT for students with disabilities. For instance, at the state-run special school for students with visual disabilities there is a technological center to equip students with basic computer skills (Al-Balushi, Al-Badi, \& Ali, 2011, p. 92).

As has been highlighted so far, there are concrete signs that the country is moving toward inclusion and equality. However, the gap between theory and practice - between promising legal reforms for people with disabilities and implementing new conceptual developments - is yet to be filled.

\section{The Setting}


People with visual disabilities are a service target group (Foster \& Resnikoff, 2005). In Oman, this group has been specifically targeted through the National Prevention of Blindness Program. However, the education of children with visual disabilities in Oman has lagged behind compared with other Arab countries (Hadidi, 1998, p. 427). There is a lack of officially available data regarding people with disabilities in general in Oman (Al Zidjaly, 2007, p. 74; Profanter, 2009). Statistics broken down by specific disabilities such as visual disabilities are also scarce (Hadidi, 1998, p. 424). Community-based prevalence rates of blindness are only available from the late 1990s (Ministry of Health, 1998; Khandekar et al., 2002): 1.1\% for all ages and 17,000 blind people in the population, $7 \%$ of whom are aged 40 or over. There is a $9.28 \%$ prevalence of blindness in the population under 40. The aims of Vision 2020 in Oman included the reduction of blindness to $0.7 \%$ for all ages by 2010 , and the elimination of avoidable forms by 2020 . The results so far show that a significant decline in blindness rates has been achieved, mainly among females by $1.47 \%$; however, an increase of nearly 5,000 blind people in the older population has been observed, due to population aging (Ministry of Health, 2000). Statistics concerning disability and education show that in total, 647 students were enrolled in the three state-run special schools during 2008-2009 (Ministry of National Economy, n.d.a). Of those, 112 were enrolled at the only state-run school for students with visual disabilities, of whom 52 were females and 60 were males.

\section{Methods and Material}

The data were collected through field visits to specialist state-run schools and NGOs during 2009-2011. Building on results from a pilot study conducted by Profanter during 2006-2009, interview data were gathered during 2009-2011. A list of pre-set questions was used in the interviews. As a way of getting an overall view of the perceptions of students with visual disabilities enrolled in the basic education system, 30 pupils aged 14-23 years were interviewed ${ }^{\mathrm{vi}}$. Background information was also gathered from two key participants selected on the basis of their experience and knowledge in the field of disability: a vice-president at a specialist NGO, and a religious leadervii as an authority on social welfare. Additionally, relevant literature was consulted, and government press releases and publications were analyzed to trace how disability, gender, 
and their interrelations with Omani society were portrayed. After potential interviewees had been contacted by telephone, through personal meetings, and by written communication, informed consent was obtained, and participants' confidentiality and anonymity were assured. The interviews were all recorded and subsequently transcribed. Official permission to access specialist institutions was obtained from the relevant ministries.

Cultural challenges were overcome by adopting the following strategies. The researchers found that applying wasta, viii and recruiting research assistants fluent in the interviewees' languages, helped to overcome potential barriers to participation such as language, mistrust, and societal and cultural restrictions. The status of two of the researchers as white, European females required the balancing of common ethical norms, codes, and policies in light of cultural dimensions ${ }^{i x}$. Consequently, a researcher with visual disabilities, who had first-hand experience as well as access to facilities in the field, was included on the international research team. In adopting a dual role as both insider and expert, she was critically important at every stage of the research; her wasta played a primary role in obtaining ministry approval to conduct the study, and in gaining students' trust. Research has shown that it is less common in Oman to talk about personal matters with people inside or outside the family than it is in the West (cf. Wikan, 1991; Al-Zidjaly, 2007). Disability is traditionally seen as a fate one does not question.

The data were analyzed quantitatively using SPSS. Qualitative sequences were included to put the quantitative data into context and provide a deeper understanding of individual conditions (Fontana \& Frey, 1994; Yin, 1994; Mason, 1996; Flick, 2002). The qualitative analysis took a structural thematic approach: we searched for themes based on both the empirical data and the methodological and theoretical approaches used in the study. The themes we drew upon were: a) how the students were treated by family members in relation to their visual disabilities; b) religious practice and its interrelations with gender and disability; c) gender relations among students with visual disabilities in relation to educational issues, such as access to institutions and material; d) students' access to and use of technology in everyday life; and e) students' future aspirations. For each result, a general description is given below, reporting statistics regarding students' opinions and beliefs, followed by qualitative examples in the form of paraphrased interview quotes. 


\section{Results and Discussion}

\section{Participants' Personal and Family Backgrounds}

Thirty semi-structured interviews were carried out. The mean age of participants was 18.7 years; the youngest participant was 14 years old, and the oldest 23. For ethical reasons, the study did not involve students under the age of $14 .{ }^{\times}$The sample was balanced in terms of gender: $46.7 \%$ were female, $53.3 \%$ male. The background of the sample was rather heterogeneous, with a majority of $46.7 \%$ being from Muscat Governorate and the rest from various provinces throughout the contry. This state-run special school has a higher enrollment rate among pupils from this area because of its proximity. Ten percent of interviewees were from the Ash Sharqiyah region, 20.0\% from Ad Dakhiliyah, and 23.3\% from Al Batinah..$^{x i}$ The sample's geographical background did not include anyone from the westernmost or southernmost regions, Adh Dhahirah and Al Wustan. As earlier research has shown, strong cultural and religious practices exist in the interior of Oman (cf. Eickelman, 1984; Profanter, 2009), which explains the composition of our sample. The interviewees were equally distributed across the catchment area in terms of gender; thus, there is no geographically related gender bias $\left(x^{2}=1.014, d f=3, p=.798\right)^{x i i}$. Thus, the hypothesis of a significant gender difference has to be rejected.

The family backgrounds of the participants were important for the interpretation of the data. The results showed that all participants were from rather large nuclear families. The mean of siblings in the family was 8.33: $50 \%$ had more than eight brothers and sisters. Among the participants, $73.3 \%$ reported other cases of visual impairment in the family. There seemed to be no significant association between cases of visual impairment $\left(x^{2}=.090, d f=1, p=.764\right)$ and family size. However, in some Muslim countries where a rapid fertility decline has been reported, large families remain the norm (UN Population Division, 2003, pp. 425-439).

\section{Family and Religious Practices}


In terms of their families' attitudes toward the treatment of people with visual disabilities, all participants reported that their family thought they should be treated like anybody else. There was neither a significant association between this egalitarian family attitude and cases of disability in the family $\left(x^{2}=.376, d f=1, p=.540\right)$, nor a gender-specific difference in this attitude $\left(x^{2}=1.182\right.$, $d f=1, p=.277)$. The vice-president of the specialist NGO stated that the situation for people with disabilities had changed in Oman: there was more awareness in society - for instance, television showed people with disabilities, students with disabilities could enroll on inclusive programs in ordinary schools, and special schools organized open days when people from wider society could come to visit.

However, some interviewees stated that difficulties had existed and still did so. Moein, aged 18, said that his family had accepted his disability by stating: "what else is there to do?" Khaleed, aged 21, said that at first his family had had difficulties; they had made him visit hospitals and institutions, but after some time they had accepted that his disability was part of life. Zubayda, aged 20, said her parents had not come to terms with her visual disability. They were stressed out, looking for hospitals all the time. She was not treated equally; her siblings were treated better, since they were taken out while she was left at home. As Profanter (2009) has shown, wider society is not totally accepting of people with disabilities. This makes it more difficult for some families to accept that their child has disabilities.

Another difficulty experienced by some interviewees was a feeling of difference. Noor, aged 23, said that at home she felt less independent than her siblings, although her family took the view that people with visual disabilities should be treated equally. Independence was related to the issue of assistance, a common topic raised by female interviewees. This was mostly to do with spending time outside the home. Some female interviewees said they experienced most difficulties when they needed assistance. Hamida, aged 17, said she felt like everyone else; she was aware that she needed assistance, but this did not make her different. Khadeeja, aged 14, said that moving around in crowds made her feel uncomfortable. Masoumah, aged 20, said that bumping into men was the most embarrassing thing. Some of the male interviewees shared the experience of feeling different while moving around alone in public. Another experience of difference had to do with the fact that they did not see the things their friends did; the feeling that 
others saw more than them made them feel insecure. Khaleed said that difficulties arose at the supermarket or on the beach. This issue of moving around constituted a parallelism between the male and female interviewees, albeit in relation to different public and private areas. Female interviewees spent most of their time with families and female friends inside the home; male interviewees moved in traditionally "male" domains. Thus, although gender segregation was woven into their daily routines, both genders encountered a similar interrelationship between independence and disability.

The study asked whether interviewees were limited in practicing their religion (attending mosque, conducting daily prayers, and studying the Quran). Among our interviewees, 47.8\% reported visiting the mosque alone, $17.4 \%$ with parents, $8.7 \%$ with friends, and $26.1 \%$ with brothers. Statistical analysis revealed a significant gender difference $\left(x^{2}=11.840, d f=3, p=.008\right)$. Male interviewees visited the mosque significantly more often, either on their own or with parents. This is not surprising, given gender-based cultural constraints. From the interviews it became clear that our female participants only went to the mosque while on an excursion or during Ramadan. These results can be interpreted in light of interrelations between gender, religion, and cultural aspects, as many women in Oman are not obliged to go to mosque and can practice their religion at home. In line with this, our results showed that all our interviewees were obliged to study the Quran, whether at school (53.6\%), at home (7.1\%), or at Quran school (39.3\%). There was no significant gender difference $\left(x^{2}=2.158, d f=2, p=.340\right)$. An imam who was interviewed stated that people with visual disabilities were not treated differently when it came to the practice of religion. Regardless of disability, one is obliged to follow Islamic customs and practices (Al Zidjaly, 2007).

\section{Education and ICT}

All students at the school were taught Braille. The school provided Braille and large-format versions of the same pictures, schoolbooks, and texts that were used in public schools. Some interviewees, such as 18-year-old Sahle, preferred large format to Braille: "doesn't like Braille due to touch." Indeed, when asked about the availability of books, interviewees stated that their 
schoolbooks were basically large-format printouts. Noor and Tuba, as well as other interviewees, said that books were not easily available. According to Noor, students' siblings transferred material from Word into Braille. Tuba, aged 23, stated: "no textbook, homemade job." By this she meant that the books were produced on-site. Moein mentioned that these self-made copies were printed on cheap paper and therefore were not very durable. At the time of the interviews, access to computers at the school was limited because the position of computer instructor was vacant. ${ }^{\text {xiii }}$ Rabah, a 21-year-old man, said: "very disappointed, no computer, no teacher." While all students had access to computers at school, the situation at home differed: only $56.7 \%$ of interviewees, including both genders, had access to a computer at home $\left(x^{2}=2.330, d f=1, p=.127\right)$. This showed that there was no gender difference in ICT access in the interviewees' domestic environment. However, the use of computers at home differed even where there was access. Reasons for limited computer use at home were: a) some students did not have voice output at their disposal, and b) some stated that assistance in using the computer was limited. The students who used the computer searched for information, surfed the Internet, wrote, read, studied, and sent emails. Nayma, aged 21, used a Hal screen reader, and she was very keen on using the Internet. Abdulazziz, aged 19, has his own laptop with voice output and used it for emails, writing, and listening to the Quran. In general, there was an awareness of the importance of ICT among the interviewees: $71.4 \%$ said that access to a computer was very important in their lives. However, 28.6\% did not think it important, and from the interviews it became clear that this was due to their limited use and understanding of it. Masoumah said he was "not understanding it." Latif, aged 19, reported that he "doesn't know how to use it, if taught be important." This was compounded by the fact that many interviewees did not have access to voice output at home. However, no significant gender difference was found in this regard $\left(x^{2}=1.163, d f=1, p=.281\right)$. According to many interviewees, a computer was important because it enabled one to gain knowledge and information, as Rabah explained: "world at your fingertips if you know computers."

\section{Future Aspirations}


For a long time, future aspirations have been off the agenda for people with visual disabilities in Oman. But there is now a growing awareness regarding the possible inclusion of this group: $73.3 \%$ of interviewees were eager to pursue academic careers; $20 \%$ were keen to enter the workforce; but only a small percentage, 6.7\%, planned to get married. There were no specific gender differences in terms of future aspirations $\left(x^{2}=2.727, d f=2, p=.256\right)$. This result indicates that for this group, women's roles were undergoing change in relation to their self-perceptions and future careers. Khadeeja expressed her wishes for the future as: “a) work b) continue education." Masoumah expressed her wishes as: "a) college; b) study history; c) teach here [at the special school]." This result further indicates that female identities and societal roles can be altered through specific training and special-needs education. Our results revealed a high degree of interest among the students in pursuing future studies and finding an occupation. This was a way for them to gain an income, and for a small number it constitutes the basis to start their own families in the future.

\section{Conclusion}

This study gives visibility to students with visual disabilities in the Sultanate of Oman. A combination of quantitative and qualitative data has been used to shed light on students with visual disabilities and their position in society. Perceptions of visual disability from the insider's point of view have been gained and contextualized in relation to familial ties, religious practices, education, technological access and use, and culture. The students with visual disabilities that participated in this study were enrolled in the only specialist state-run school in Oman. They are not representative of all students with visual disabilities in the country, since no one from the westernmost or southernmost regions of Oman participated in the research.

Earlier research has shown that living with disability and being from a financially disadvantaged background or a remote area presents a double disadvantage, as it can exacerbate obstacles $^{\text {xiv }}$ to appropriate support services, if such services are available at all (Profanter, 2009). According to Hadidi (1998, pp. 428-429), in order for change to take place, training and counseling need to be provided for parents, and families' participation in the educational process needs to 
be increased. Consequently, there is a need to support students with disabilities and their families. Policy changes are taking place, awareness is being created, and attitudes are changing; nevertheless, perceptions and behavior still lag behind (Abu-Habib, 1997a, p. 3; Hadidi, 1998, p. 429; Al-Mawali, 2004). Our study supports these previous research findings, since many of our interviewees reported that the feeling of being different was a major issue within their families.

The extent of progress in the development of facilities for people with visual disabilities can be questioned. Improved socioeconomic conditions in Oman, combined with a government effort to allocate resources to health and education, have to some extent influenced the lives of our student interviewees, since today they are able to attend school more easily than previous generations. According to the Ministry of Education (2008a, p. 29), education should be available to all children in Oman. Education has played and still plays a part in improving living conditions in Oman (cf. Al-Barwani \& Albeely, 2007). Despite this access to education, however, there is a need to train teachers in both general and special education. This educational training was not standard for the teachers at the time of our study: 60 teachers were on the team for the academic year 2010-2011; of those, some were trained in general education, and some were trained in special education, but none was trained in both. This need for trained teachers can be related to some of Hadidi's (1998, pp. 428-429) suggested policy priorities to alter the situation of children with visual disabilities. She outlines a shortage of Omani teachers qualified in the education of children with disabilities, and she urges the development of such training for teachers from Oman. Another important issue Hadidi highlights is the development and adaptation of a curriculum designed for students with visual disabilities. At the only school for pupils with visual disabilities in Oman, there is no special curriculum; the general curriculum is followed, with small adjustments. Moreover, the poor availability of schoolbooks is a sign of the need for greater investment to provide students with proper educational materials and technology. When it comes to future aspirations, most of our interviewees aimed to attend further education. Khandekar and Al Harby (2006, pp. 175-176) highlight the limitations of vocational training for blind people in Oman. Students with visual disabilities have the opportunity to study at university level, but as Al-Balushi, Al-Badi, and Ali (2011, p. 92) state, "the blind get very limited options at Sultan Qaboos University since the College of Arts is the only College that caters for the needs of blind students." 
The role of ICT in the curriculum needs to be re-evaluated and further developed. As research has shown, ICT offers a promising way for students to join the workforce and be part of the community. As our results show, in the domestic arena as well as the educational arena, use of and access to technology needs to be attuned to the students' constructed meanings of their own disabilities. Thus, it is not a matter of just placing a computer in front of a person with a visual disability. In order for it to be used, it needs to be related to the individual's needs and capabilities (Näslund, 2009). Both infrastructural issues and their interrelations with gender and disability need to be taken into consideration. Another issue, highlighted in Alqaryouti's research with students with visual disabilities in higher education in Oman (2010, p. 221), is that skilled teachers who are familiar with disability issues and assistive technologies need to be trained. The interviewees in our study confirmed this need for trained teachers: they did not receive enough assistance in ICT training due to a lack of computer teachers at the school. Additionally, teachers are important for teaching the benefits of ICT skills as a way to get into the workforce.

Gender issues and their interrelations with disability need to be further explored. Omani society is based on gender segregation in everyday life. Some areas are dominated by women (domestic services), while in other areas (going to mosque, dealing with authorities) men are at the forefront. Previous findings about the gendered aspects of marriage that come into play for people with disabilities show that there is a clear disbalance. As Abu-Habib (1997b, p. 74) states, it is commoner for a man with disability to find a partner without a disability than it is for a woman with disability to do the same. Our study reveals no gender difference in family attitudes. This result can be explained in the following ways: on the one hand, it may be related to the religious understanding of disability and the notion of equality outlined earlier (cf. Bradshaw, Tennant, \& Lydiatt, 2004). On the other hand, the interviewees' family background was quite privileged ${ }^{x v}$ in the sense that cultural and social discrimination did not come into play. An additional explanation is that changes in wider society may be a sign of increased awareness.

Despite investments to create greater awareness in general, disability is still widely regarded as an individual obstacle. Disability as defined by Royal Decree 63/2008 mostly focuses on the individual and her/his shortcomings. This implies that disability is concerned with the individual body, rather than with its interrelation with the wider society. However, recent 
initiatives such as programs to raise awareness are promoting a shift toward the social model (AlMawali, 2004). Still, there is a need to view disability from a relational viewpoint (Shakespeare, 2006). This viewpoint is important, because it will enable the creation of infrastructure to take account of the lifelong aspects of disability, as well as its gender aspects: both a) the individual's everyday life (the body) and b) her/his interrelations with wider society (in its familial, political, religious, historical, and cultural aspects). The obstacles to a good educational grounding in these ideas include educators themselves, other students, and facility adaptations (cf. Al-Abdulwahab \& Al-Gain, 2003, p. 68). If these obstacles are overcome, Omani society will be able to provide services tailored to the wishes and needs of students with disabilities. It is important to take the interrelations between gender and disability into account so that suggestions for the future can be clearly located and situated.

\section{Notes}

'The following sections were written by Annemarie Profanter: Context and Contextualization, The Disability Network, The Setting, Methods and Material, Results and Discussion: Family and Religious Practices, Results and Discussion: Future Aspirations, Conclusion. The quantitative analysis was carried out by Profanter. The following sections were written by Rebecka Näslund: Abstract and Introduction, Disability and Gender, Results and Discussion: Participants' Personal and Family Backgrounds, Results and Discussion: Education and ICT. Shariffa Khalid Qais Al Said assisted in the obtainment of official approval, recruitment, and data collection. The researchers gratefully acknowledge the help of all people involved in the study who provided support in various ways at its various phases.

ii A study by Profanter (2009) served as a pilot for this research.

iii In light of ethical guidelines for research in the social sciences, more detailed information about the profiles and positions of the interviewees cannot be revealed, as the anonymity and safety of participants must be guaranteed.

iv In Oman, diversity among women and men in terms of ethnicity, age, religion, class, sexual orientation, and disability are rarely explored. Consequently, our research attempts to make a contribution by focusing on disability and gender.

${ }^{v}$ Although the development of a modern infrastructure in Oman is regarded as the personal achievement of His Majesty Sultan Qaboos, he is the longest-serving ruler in the Middle East, and the question of his succession is an ongoing concern (Reidel, 2015).

${ }^{v i}$ This age group, $14-23$ years, covers $25 \%$ of the total students enrolled in this special school.

vii The religious leader was interviewed to gain a deeper understanding of the interrelations between Islam, culture, and disability.

viii Wasta is often called the hidden force of the Middle East: the concept of wasta permeates all aspects of society, and involves both the act and the person who mediates or intercedes to find a middle ground. The head of the family performs wasta services by obtaining for the supplicant what is assumed to be otherwise 
unattainable. Wasta is a force in all significant decision-making, yet it is not openly discussed in Omani society.

${ }^{\text {ix }}$ As Western researchers we have been aware of our status as white, privileged academics attempting to move into very different cultural situations. In order to take differing views and expectations into account, be open to differing inclusive policies and practices and be able to develop culturally sensitive instruments partnerships and collaborations were sought .

' Personal information has been altered to guarantee participants' anonymity and confidentiality (British Psychological Society, 2009).

xi The Sultanate of Oman is divided administratively into four governorates (Muscat, Dhofar, Musandam, and Al Buraimi) and five regions (Al Batinah, Adh Dhahirah, Ad Dakhiliyah, Ash Sharqiyah, and Al Wusta) (Ministry of Information, 2011).

xii For hypothesis testing chi-squared tests were carried out. It is used for testing relastionships between categorical variables. The null hypothesis of the Chi-Square is that no relationship exists on the categorical variables in the populaiton; they are independent.

xiii After completion of the study, computer instructors were hired, and a computer class ran as usual.

xiv Some of these obstacles include societal perceptions, traditional medical practices, illiteracy among parents and elders, and lack of suitable adaptations in educational facilities.

${ }^{x V}$ It should be recalled here that the sample did not include any participants from the westernmost or southernmost areas of Oman.

\section{References}

Abu-Habib, L. (1997a). 1. Introduction. In L. Abu-Habib (Ed.), Gender and disability: Women's experiences in the Middle East (pp. 1-8). UK and Ireland: Oxfam.

Abu-Habib, L. (1997b). 4. Conclusion: making 'imperfect' women visible; strategies for the future. In L. AbuHabib (Ed.), Gender and disability: Women's experiences in the Middle East (pp. 73-84). UK and Ireland: Oxfam.

Al-Balushi, T., Al-Badi, A. H., \& Ali, S. (2011, October). Prevalence of disability in Oman: Statistics and challenges. Canadian Journal of Applied Sciences, 1(3), 81-96. Retrieved July 13, 2012, from http://cpanel.canajas.ca/panel/A/1\%20AlBalushi.pdf

Al-Barwani, T. A., \& Albeely, T. S. (2007). The Omani family: Strengths and challenges. Marriage \& Family Review, 41(1/2), 119-142.

Al-Abdulwahab, S., \& Al-Gain, S. I. (2003). Attitudes of Saudi Arabian health care professionals towards people with physical disabilities. Asia Pacific Disability Rehabilitation Journal, 1(14), 63-70.

Al-Krenawi, A., Graham, J. R., Dean, Y. Z., \& Eltaiba, N. (2004). Cross-National study of attitudes towards seeking professional help: Jordan, United Arab Emirates (UAE) and Arabs in Israel. International Journal of Social Psychiatry, 50(2), 102-114.

Al-Mawali, Y. B. (2004). The everyday lives of physically disabled young people in Oman: Barriers to social inclusion. Doctoral dissertation, Durham University , UK. Retrieved May 11, 2012, from http://etheses.dur.ac.uk/1936/1/1936.pdf?EThOS (BL)

Alqaryouti. I. A. (2010). Inclusion the disabled students in higher education in Oman. International Journal for Cross-Disciplinary Subjects in Education, 1(4), 216-222.

Al Zidjaly, N. (2007). Alleviating disability through Microsoft PowerPoint: the story of one quadriplegic man in Oman. Visual Communication, 6(1), 73-98. 
Al Zidjaly, N. (2009). Agency as an interactive achievement. Language in Society, 38(2), 177-200.

Ashencaen Crabtree, S. (2008). Dilemmas in international social work education in the United Arab Emirates: Islam, localization and social need. Social Work Education, 27(5), 536-548.

Atshan, L. (1997). 3.4. Disability and gender at a cross-roads: a Palestinian perspective. In L. Abu-Habib (Ed.), Gender and disability: Women's experiences in the Middle East (pp. 53-59). UK and Ireland: Oxfam.

Bradshaw, K., Tennant, L., \& Lydiatt, S. (2004). Special education in the United Arab Emirates: Anxieties, attitudes and aspirations. International Journal of Special Education, 19(1), 49-55.

Braidotti, R. (2002). The uses and abuses of the sex/gender distinction in European feminist practices. In G. Griffin \& R. Braidotti (Eds.), Thinking differently: A reader in European women's studies (pp. 285-308). London and New York: Zed Books.

Butler, J. (1999). Gender trouble: Feminism and the subversion of identity. New York and London: Routledge. Butler, J. (2004). Undoing gender. New York and London: Routledge.

Eickelman, C. (1984). Women and community in Oman. New York and London: New York University Press.

Flick, U. (2002). An Introduction to qualitative research (2nd ed.), London, Thousand Oaks \& New Delhi: SAGE Publications.

Fontana, A., \& Frey. J. H. (1994). 22. Interviewing: The art of science. In N. K. Denzin \& Y. S. Lincoln (Eds.), Handbook of qualitative research (pp. 361-376). Thousand Oaks, London \& New Delhi: SAGE Publications.

Foster, A., \& Resnikoff, S. (2005). The Impact of Vision 2020 on global blindness. Eye, 19(10), 1133-1135.

Hadidi, M. S. Z. (1998). Education of children with vision impairments in the Sultanate of Oman. International Journal of Disability, Development and Education, 45(4), 423-429.

International Trade Union Confederation - ITUC (2008). Internationally-Recognised Core Labour Standards in the Sultanate o Oman: Report for the WTO General Council Review of Trade Policies of the Sultanate of Oman. Retrieved March, 2009, from http://www.ituc-csi.org/IMG/pdf/TPR_Oman.Final.pdf

Khandekar, R., Mohammed, A. J., Negrel, A. D., \& Al Riyami, A. (2002). The prevalence and causes of blindness in the Sultanate of Oman: The Oman Eye Study (OES). Br J Ophthalmol, 86(9), 957-962.

Khandekar R., \& Al Harby, S. (2006). National register for the blind: A tool for health programme management. La Revue de Santé de la Méditerranée orientale, 12(1/2), 170-177.

Khandekar, R., Mohammed, A. J., \& Al Raisi, A. (2007). Prevalence and causes of blindness \& low vision; before and five years after 'Vision 2020' initiatives in Oman: A review. Ophthalmic Epidemiology, 14, 9-15.

Mason, J. (1996). Qualitative researching, London, Thousand Oaks \& New Delhi: SAGE Publications.

Miller, J. (1997). Creating modern Oman: An interview with Sultan Qabus. Foreign Affairs, 76(3), 13-18.

Ministry of Education. (n.d.) The program for the inclusion of students with special needs.

Ministry of Education, Sultanate of Oman. (2008a). Inclusive education in the Sultanate of Oman. National report of the Sultanate of Oman - 2008. Inclusive education. The way of the future.

Ministry of Education, Sultanate of Oman. (2008b). ICT and education in the Sultanate of Oman.

Ministry of Health. (1998). Blindness Survey Report; Oman Eye Study (OES), Muscat: Mazoon Printing Press.

Ministry of Health. (2000). Oman Corneal Diseases in Eye Health Care Manual (2nd ed.), Muscat: Al Zahra Printers.

Ministry of Information. (2011). Regions and Governates of Sultanate of Oman. Retrieved May 8, 2011, from http://www.omanet.om/english/regions/oman.asp

Ministry of National Economy. (n.d. a). Education Indicators. Retrieved September 6, 2011, from http://www.moneoman.gov.om/book/SYB2010/19-Education.pdf

Ministry of National Economy. (n.d. b). "Population Series": Disabled statuses in Sultanate of Oman. Retrieved September 8. 2011, from http://www.mone.gov.om/PublicationAttachment/Disabled_EN.pdf

Näslund, R. (2009). Bringing actors together: ICT, disability and pupils in special school. Licentiate dissertation, Luleå University of Technology.

Näslund, R., \& Gardelli, Å. (2013). 'I know, I can, I will try': Youths and adults with intellectual disabilities in Sweden using information and communication technology in their everyday life. Disability \& Society. 28(1), 28-40. 
Ohlin, C. (1995). Special education in Oman : primary school teachers' perception of children with learning disabilities. Doctoral dissertation, Lund University.

Oliver, M. (1996). Understanding disability: From theory to practice. London: Macmillan.

Profanter, A. (2009). Facing the challenges of children and youth with special abilities and needs on the fringes of Omani society. Children and Youth Services Review, 31(1), 8-15.

Reidel, B. (2015, February 13). After Qaboos who will be Oman's next sultan? Retrieved from http://www.almonitor.com/pulse/originals/2015/01/oman-abdullah-qaboos-succession-poweryemen.html\#\#ixzz3RcrjDJ9K

Shakespeare, T. (2006). Disability rights and wrongs. London \& New York: Routledge.

Traustadóttir, R., \& Kristiansen. K. (2004). 1. Introducing gender and disability. In K. Kristiansen. \& R. Traustadóttir (Eds.), Gender and disability research in the Nordic countries (pp. 31-48). Lund: Studentlitteratur.

The British Psychology Association. (2009). Ethics and Standards. Retrieved June 11, 2012, from http://www.bps.org.uk/what-we-do/ethics-standards/ethics-standards

UN Population Division. (2003). World Population Prospects: The 2002 Revision Xvi. United Nations Population Division.

Wikan, U. (1991). Behind the Veil in Arabia: Women in Oman. Chicago and London: The University of Chicago Press.

Yin, R. K. (1994). Case study research: Design and methods (2nd ed.), Thousand Oaks, London \& New Delhi: SAGE Publications. 